\title{
POSSIBILITIES OF NUS AND IMPACT-ECHO METHODS FOR MONITORING STEEL CORROSION IN CONCRETE
}

\author{
MOŽNOSTI METOD NUS IN UDAREC-ODMEV ZA KONTROLO \\ KOROZIJE JEKLA V BETONU
}

\author{
Kristýna Timčaková-Šamárková, Michal Matysík, Zdeněk Chobola \\ Brno University of Technology, Faculty of Civil Engineering, Institute of Physics, Veveri 331/95, 60200 Brno, Czech Republic \\ samarkova.k@fce.vutbr.cz \\ Prejem rokopisa - received: 2015-06-30; sprejem za objavo - accepted for publication: 2015-08-25
}

doi:10.17222/mit.2015.149

\begin{abstract}
The corrosion of steel elements in reinforced concrete can cause considerable damage to civil-engineering structures. Early detection of rust is therefore very important. The aim of this paper is to evaluate the possibility of using nonlinear ultrasonic spectroscopy with a single exciting harmonic frequency and the impact-echo method for monitoring the corrosion of concrete-covered steel. For the research we manufactured concrete beams, reinforced with a standard reinforcing-steel bar passing through their centre. After concrete curing and drying, the samples were exposed to a $20 \%$ carbon dioxide atmosphere. After the concrete $\mathrm{pH}$ decreased below 9.6 throughout the sample volume, the samples were immersed into a $5 \%$ water solution of $\mathrm{NaCl}$ and subsequently placed into a drying oven. Measurements were carried out before the carbonation of the concrete, after it, and then after every 20th cycle of the accelerated degradation by chlorides. Nonlinear-ultrasonic-spectroscopy (NUS) methods are based on the fact that crack-induced nonlinearity makes a sensitive material-impairment indicator. The impact-echo method uses short-time mechanical impulses applied to the surface of a test sample, producing elastic waves. These waves spread throughout the sample and reflect from the surface but also from the microcracks and unobservable defects inside the sample. To verify the correctness of the NUS and impact-echo-method results, additional measurements were carried out (a confocal scanning microscope). It was proved that both methods could be used for monitoring the corrosion of concrete-covered
\end{abstract} steel.

Keywords: impact-echo, reinforced concrete, nonlinear ultrasonic spectroscopy, steel corrosion, confocal microscopy

Korozija jeklenih elementov v ojačanem betonu lahko povzroči občutne poškodbe v zgradbah. Zgodnje odkrivanje rje je zato zelo pomembno. Namen tega članka je oceniti možnosti uporabe nelinearne ultrazvočne spektroskopije z vzbujajočo harmonično frekvenco in metodo udarec-odmev za kontrolo korozije jekla, pokritega z betonom. Za preiskavo so bili izdelani betonski stebri, ki so bili ojačani s standardno rebričasto jekleno palico, nameščeno po sredini stebra. Po strjevanju in sušenju betona so bili vzorci izpostavljeni atmosferi $20 \%$ ogljikovega dioksida. Ko se je pH betona zmanjšal pod 9.6 po vsem volumnu vzorca, so bili vzorci potopljeni v $5 \%$ vodno raztopino $\mathrm{NaCl}$ in nato nameščeni v peč za sušenje. Meritve so bile izvedene pred karbonacijo betona, po njej in nato po vsakem 20 ciklu pospešene degradacije s kloridi. Metode nelinearne ultrazvočne spektroskopije (NUS) temeljijo na dejstvu, da zaradi razpoke povzročena nelinearnost povzroči indikator oslabitve materiala. Metoda udarec-odmev uporablja kratkotrajne mehanske udarce na površini preizkušanca, kar povzroči elastične valove. Ti valovi se širijo skozi vzorec in se odbijajo od površine in tudi od mikrorazpok in nevidnih napak znotraj vzorca. Za preverjanje pravilnosti rezultatov metode NUS in metode udarec-odmev so bile opravljene dodatne meritve s konfokalnim vrstičnim mikroskopom. Potrjeno je bilo, da sta obe metodi uporabni za kontrolo korozije z betonom pokritega jekla.

Ključne besede: metoda udarec-odmev, armiran beton, nelinearna ultrazvočna spektroskopija, korozija jekla, konfokalna mikroskopija

\section{INTRODUCTION}

Steel-reinforced concrete parts can be threatened by corrosion. The corrosion of steel elements in concrete decreases the lifetime of affected constructions and negatively changes their properties. Steel in concrete is usually in a non-corroding, passive condition. But if chloride moves into the concrete, it violates the passive layer protecting the steel, causing it to rust. Another reason for steel corrosion in concrete is carbonation. The alkaline environment in concrete protects steel from corrosion. However, a problem may activate carbon dioxide, which reduces the $\mathrm{pH}$ value of concrete. Under these conditions steel is no longer passive and can start to corrode. ${ }^{1}$

This article describes the monitoring of corrosion, caused by carbonation of concrete and supported by active chlorides, using nonlinear ultrasonic spectroscopy and the impact-echo method. The paper presents the results obtained for reinforced concrete samples with one steel rod passing through the centre.

The first method used for corrosion monitoring was nonlinear ultrasonic spectroscopy with one ultrasonic excitation signal. On the basis of nonlinear effect studies, new diagnostic and defectoscopic methods were designed. These methods are called the nonlinear ultrasonic spectroscopy. The nonlinear ultrasonic spectroscopy brings new perspectives into the acoustic non-destructive testing of material degradation. The material inhomogeneity and, sometimes, the shape complexity of some parts used in civil engineering heavily decrease the applicability of "classical" ultrasonic methods. These linear acoustic methods focus on the energy of waves, reflected by structural defects, variations in the wavepropagation velocity or changes in the wave amplitude. 
However, none of these "linear" wave characteristics is as sensitive to structural defects as the specimen nonlinear response. In this way, nonlinear methods open up new horizons in non-destructive ultrasonic testing, providing high sensitivities, application speeds and an easy interpretation. One of the fields, in which a wide application range of nonlinear ultrasonic spectroscopy methods can be expected, is civil engineering. It is predicted that these advanced techniques can contribute a great deal to the improvement and refinement of defectoscopic and testing methods in the building-industry practice. ${ }^{2,3}$

In this article, we focused on one type of the NUS methods - NUS with a single harmonic excitation ultrasonic signal. This method was used in the experimental part. In this case, where a single exciting frequency, $f_{1}$, is used, the nonlinearity gives rise to other harmonic signals, whose frequencies $f_{\mathrm{v}}$ obey the Fourier series equations:

$$
f_{v}=n f_{1} ; n=0,1,2, \ldots \infty
$$

In general, these frequency-component amplitudes decrease when the harmonic-order natural number, $n$, increases. If the nonlinearity effect is not entirely symmetrical, there can be changes in the amplitudes. ${ }^{3-5}$

The second method used for the corrosion monitoring was the impact-echo method. It is based on the acoustic properties of a material, which depend on its condition. A short-time mechanical impulse, usually caused by a hit of a hammer or a falling steel ball, spreads throughout the sample in the form of elastic waves. These waves are reflected from the surface of the sample and also from the micro-cracks and unobservable defects inside the sample and they are thus transformed. On another location on the sample surface, piezoelectric sensors subsequently detect these transformed waves as the response signal. ${ }^{6-8}$ The signal analysis within the impact-echo method is most frequently performed on the basis of the frequency spectra obtained from the fast Fourier transform. Usually we monitor the changes in the dominant frequency depending on the damage of the material structure. This method has a wide application in mechanical engineering, power engineering and in many industries as well as in civil engineering due to its simplicity and quick procedure. ${ }^{9-11}$

In addition, the sample surface was observed using a confocal microscope. In the conventional microscopy, not only is the plane of focus illuminated, but much of the specimen above and below this point is also illuminated resulting in an out-of-focus blur from these areas. This out-of-focus light leads to a reduction in the image contrast and a decrease in the resolution. In the confocal microscope, all out-of-focus structures are suppressed during the image formation. The detection pinhole does not permit the rays of light from out-of-focus points to pass through it. The wavelength of the light, the numerical aperture of the objective and the diameter of the diaphragm (a wider detection pinhole reduces the confocal effect) affect the depth of the focal plane. To obtain a full image, the point of light is moved across a specimen using scanning mirrors. The emitted/reflected light passing through the detector pinhole is transformed into electrical signals and processed by a computer.

\section{EXPERIMENTAL SECTION}

For the research, beams with dimensions of $50 \mathrm{~mm} \times$ $50 \mathrm{~mm} \times 330 \mathrm{~mm}$ were made. They were reinforced with one standard reinforcing bar with a $10 \mathrm{~mm}$ diameter and a length of $400 \mathrm{~mm}$, passing through the centre of the sample. For the production of concrete, we used a mixture composed of $300 \mathrm{~kg}$ of cement CEM II/B - S 32.5, $1350 \mathrm{~kg}$ of sand with an aggregate fraction of $0-4 \mathrm{~mm}$ and $225 \mathrm{~L}$ of water. The concrete had a high watercement ratio to allow an easy penetration of degradation agents into the concrete structure. After $24 \mathrm{~h}$, when these samples were in the form, they were cured in water for the following $27 \mathrm{~d}$ and then they were dried to natural humidity at room temperature. Thus prepared samples were exposed to $20 \%$ carbon dioxide at $80 \%$ humidity and a temperature of $26{ }^{\circ} \mathrm{C}$. The carbonation lasted for $60 \mathrm{~d}$ and the $\mathrm{pH}$ decreased below the value of 9.6 throughout the sample volume. Then the samples underwent an accelerated degradation by chlorides, when they were immersed into a $5 \%$ water solution of $\mathrm{NaCl}$ for 16 $\mathrm{h}$; subsequently, they were placed into a drying oven with an air temperature of $40{ }^{\circ} \mathrm{C}$ for $8 \mathrm{~h}$. The measurement was carried out before the carbonation of the concrete, after the carbonation and after every 20th cycle of the accelerated degradation by chlorides. We performed a total of 100 degradation cycles.

The transmitting part for the NUS with a single harmonic ultrasonic signal consists of four functional blocks: a controlled-output-level harmonic-signal generator, a low-distortion $100 \mathrm{~W}$ power amplifier, an output low-pass filter to suppress higher harmonic components and ensure high purity of the exciting harmonic signal and a piezoceramic transmitter (actuator) to ensure the ultrasonic excitation.

The receiving section consists of a piezoceramic sensor, a low-noise preamplifier, an amplifier with bandpass filters, an oscilloscope and a computer. The measuring apparatus is schematically shown in Figure 1.

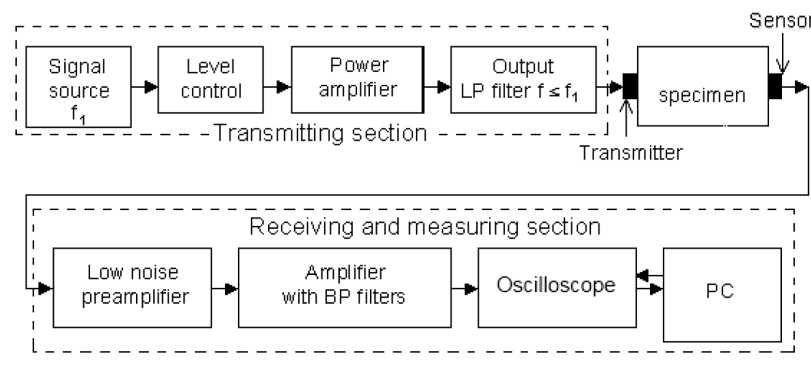

Figure 1: Scheme of non-linear ultrasonic spectroscopy with an ultrasonic-excitation-signal measuring apparatus

Slika 1: Shema nelinearne ultrazvočne spektroskopije z napravo za merjenje ultrazvočno zbujenega signala 


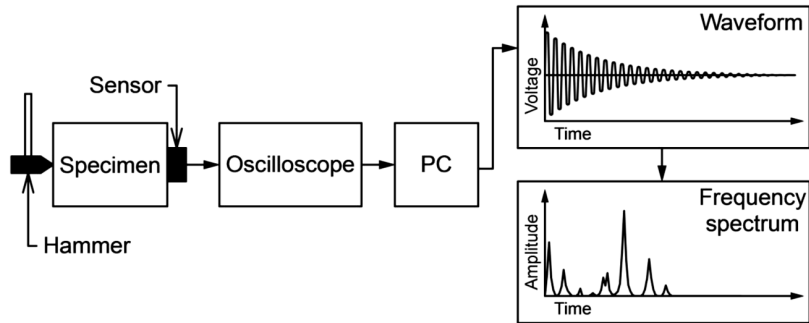

Figure 2: Scheme of the impact-echo method Slika 2: Shema metode udarec - odmev

For the recorded data to be interpreted properly, each of the measuring instruments must meet the following criteria:

- High linearity of all the instruments (generators, amplifiers, sensor, transmitter, etc);

- High resolution in the frequency domain;

- High dynamic range (90-130 dB);

- Highly efficient filtration of detected signals;

- Frequency range of $10 \mathrm{kHz}$ to $10 \mathrm{MHz}$;

- Optimized sensor and transmitter location.

We also constructed a measuring apparatus for the impact-echo method. In this case, a hanging hammer weighing $12 \mathrm{~g}$ was used and the hit was carried out from a predetermined height, which was the same for all the measurements. A MIDI piezoelectric sensor measured the signal response, which was fed to the input of a twochannel oscilloscope (TiePie engineering Handyscope HS3). The sensor was placed on the surface of concrete and the hit was carried out on uncovered reinforcement. ${ }^{12,13}$ A scheme of the impact-echo method is shown in Figure 2.

An Olympus LEXT 3100 laser confocal scanning microscope was used to study the surface and cracks of the specimens. The microscope uses an Ar laser bluegreen spectral line with a wavelength of $488 \mathrm{~nm}$, which makes it possible to gain very high-precision 3D imaging and measurement. The microscope resolution power is: superficial, $120 \mathrm{~nm}$; sectional, $40 \mathrm{~nm}$.

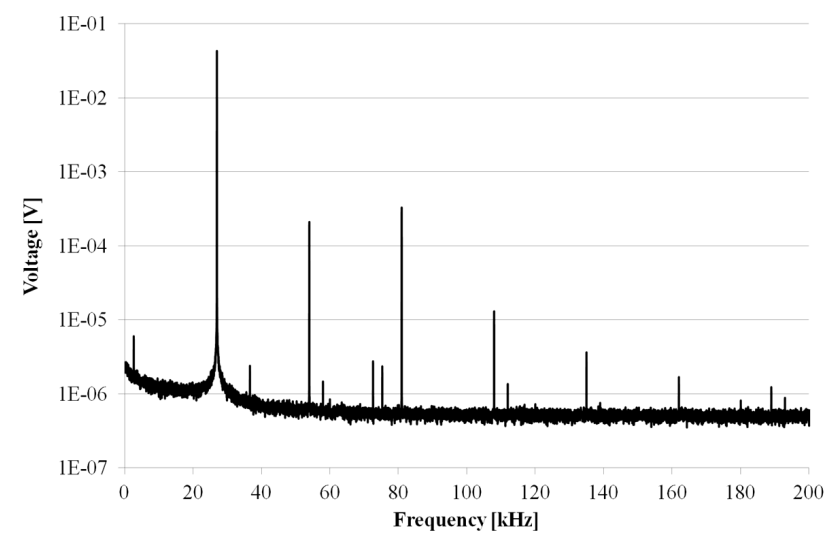

Figure 3: Frequency spectrum, obtained with the NUS method, for specimen $\mathrm{C} 432$ before carbonation

Slika 3: Spekter frekvenc, dobljen z metodo NUS na vzorcu C432 pred karbonacijo

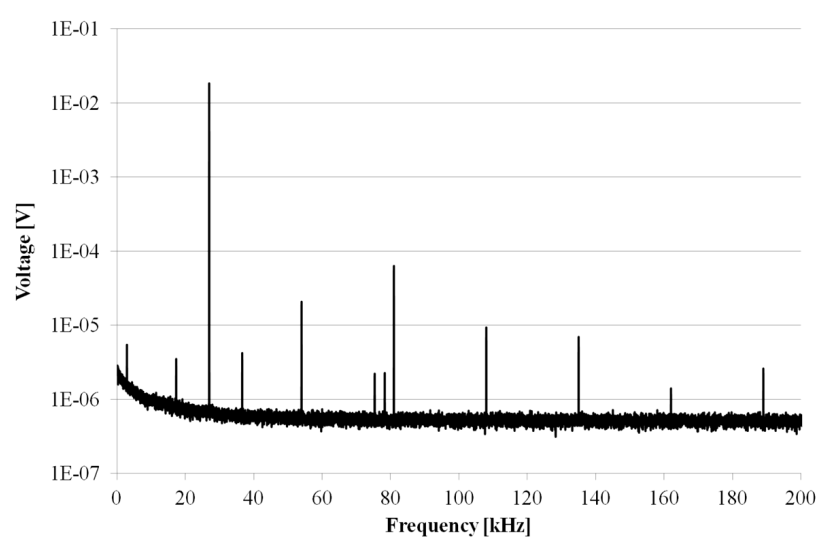

Figure 4: Frequency spectrum, obtained with the NUS method, for specimen $\mathrm{C} 432$ after carbonation

Slika 4: Spekter frekvenc, dobljen z metodo NUS na vzorcu C 432 po karbonaciji

\section{RESULTS AND DISCUSSION}

All the measurement results of individual methods are represented by sample $\mathrm{C} 432$ and sample C435. Predegradation measurements obtained with the NUS method for specimen C432 are shown in Figure 3. Figure 4 shows the frequency spectrum of the same specimen after carbonation and Figure 5 shows the frequency spectrum of specimen $\mathrm{C} 432$ after 100 cycles of the accelerated degradation by chlorides. We used the same exciting power and the same exciting frequency. The transmitter was on the steel bar, the sensor was mounted on the concrete. We could see a significant amplitude decrease in the first and especially in the third harmonic frequencies. There was also growth in the numbers and amplitudes of the non-harmonic frequencies, which was typical for this measurement configuration for all the specimens. As an example, we present specimen C435 too (Figures 6 to 8 ).

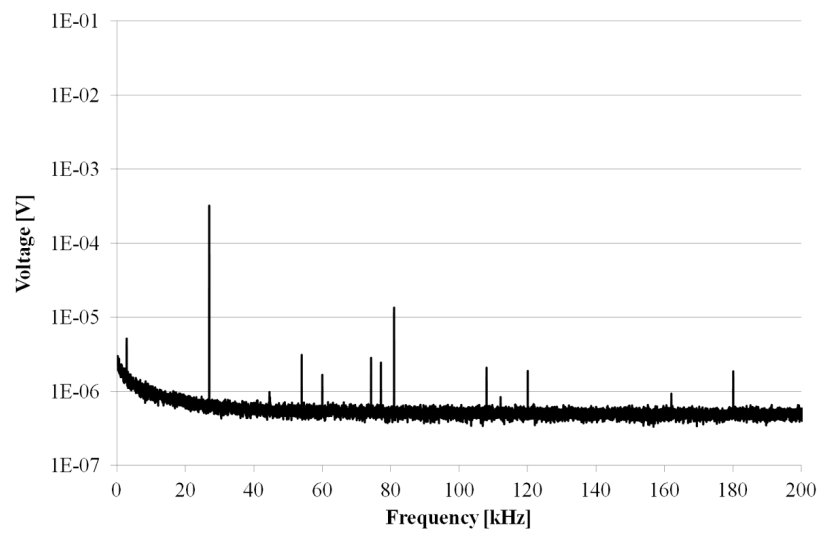

Figure 5: Frequency spectrum, obtained with the NUS method, for specimen C432 after 100 cycles of accelerated degradation by chlorides

Slika 5: Spekter frekvenc, dobljen z metodo NUS na vzorcu C432 po 100 ciklih pospešene degradacije s kloridi 


\section{K. TIMČAKOVÁ-ŠAMÁRKOVÁ et al.: POSSIBILITIES OF NUS AND IMPACT-ECHO METHODS FOR MONITORING ...}

The dominant frequency of the frequency spectrum obtained with the impact-echo method for sample C432 before the degradation by carbon dioxide was at position

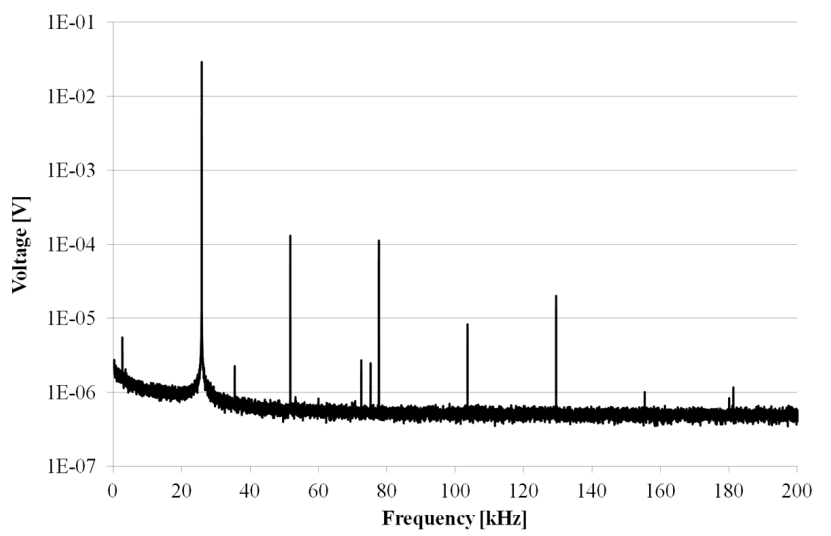

Figure 6: Frequency spectrum, obtained with the NUS method, for specimen $\mathrm{C} 435$ before carbonation

Slika 6: Spekter frekvenc, dobljen z metodo NUS na vzorcu C435 pred karbonacijo

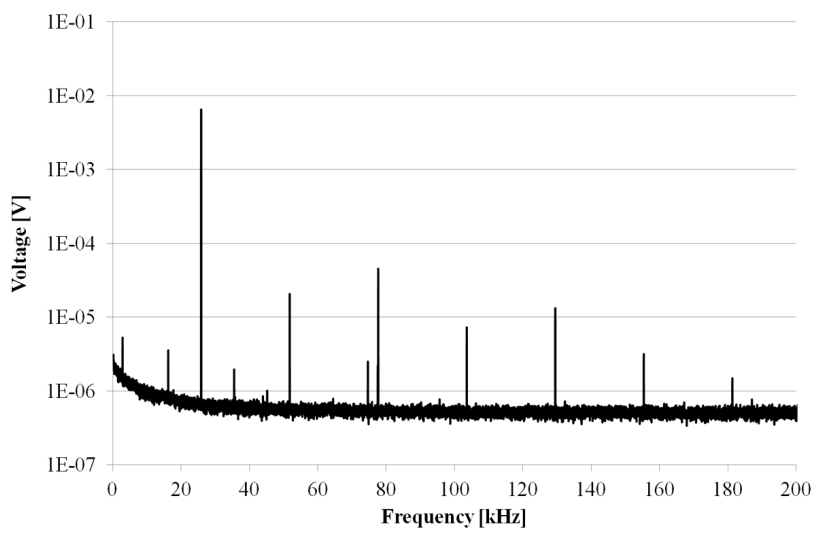

Figure 7: Frequency spectrum, obtained with the NUS method, for specimen $\mathrm{C} 435$ after carbonation

Slika 7: Spekter frekvenc, dobljen z metodo NUS na vzorcu C 435 po karbonaciji

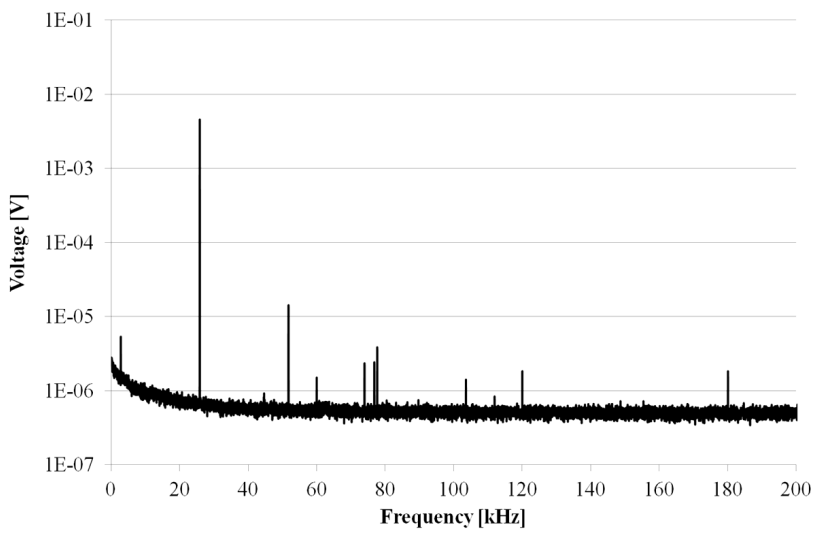

Figure 8: Frequency spectrum, obtained with the NUS method, for specimen $\mathrm{C} 435$ after 100 cycles of accelerated degradation by chlorides

Slika 8: Spekter frekvenc, dobljen z metodo NUS na vzorcu C435 po 100 ciklih pospešene degradacije s kloridi
$10869 \mathrm{~Hz}$. After the carbonation of the concrete, this frequency moved to $10172 \mathrm{~Hz}$ and after 100 cycles of the accelerated degradation by chlorides, the value of this dominant frequency was $9950 \mathrm{~Hz}$. These frequency

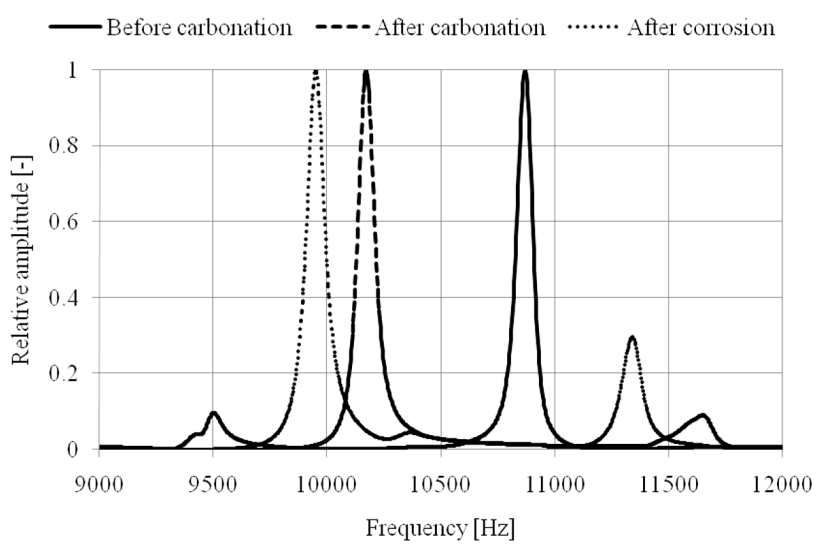

Figure 9: Frequency shifts during the degradation of specimen C432, obtained with the impact-echo method

Slika 9: Zamik frekvenc med degradacijo vzorca C432, dobljen z metodo udarec-odmev

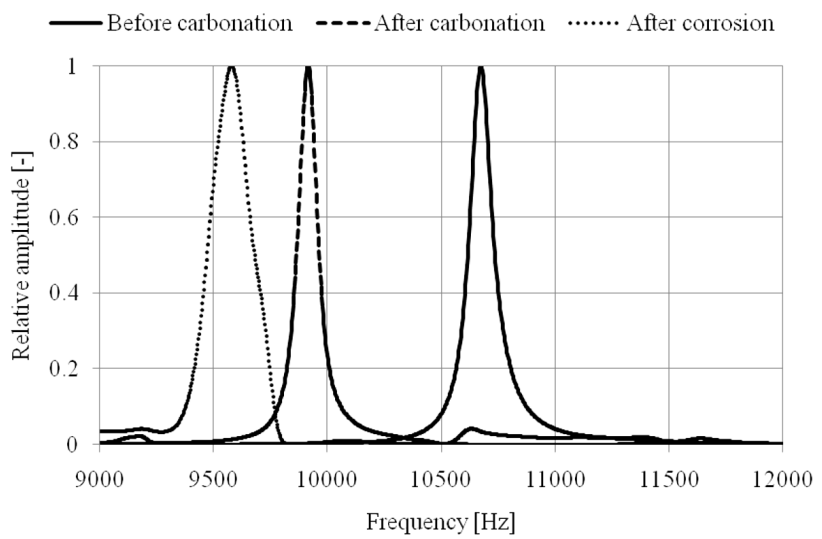

Figure 10: Frequency shifts during the degradation of specimen $\mathrm{C} 435$, obtained with the impact-echo method

Slika 10: Zamik frekvenc med degradacijo vzorca C435, dobljen z metodo udarec-odmev

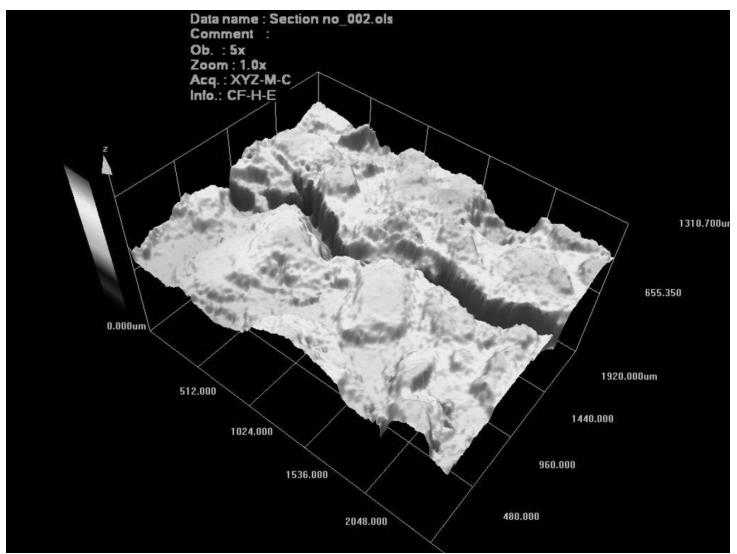

Figure 11: Crack in specimen C432 after 40 cycles of accelerated degradation by chlorides

Slika 11: Razpoka v vzorcu C432 po 40 ciklih pospešene degradacije s kloridi 


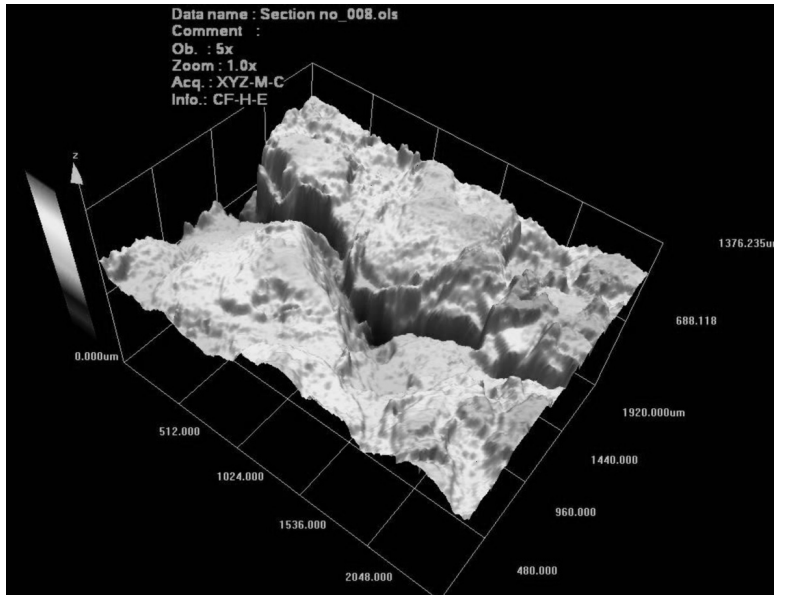

Figure 12: Crack in specimen C432 after 60 cycles of accelerated degradation by chlorides

Slika 12: Razpoka v vzorcu C432 po 60 ciklih pospešene degradacije s kloridi

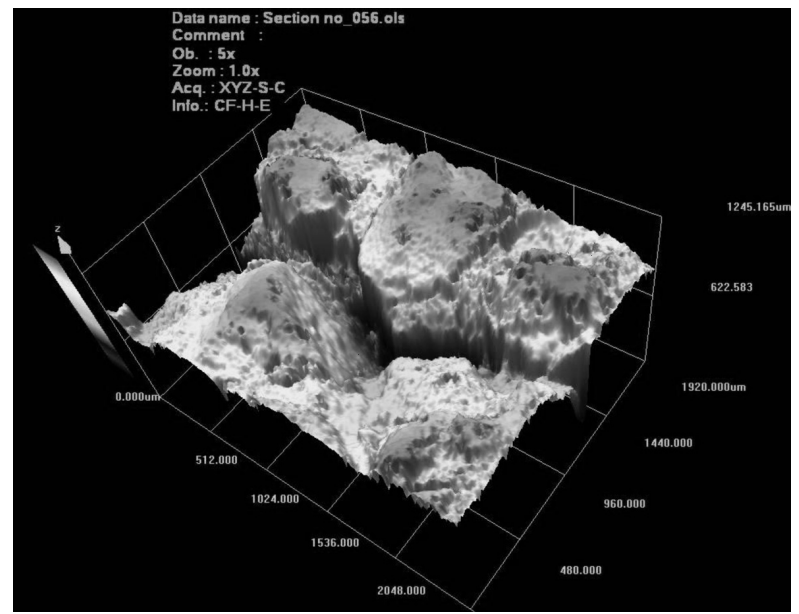

Figure 13: Crack in specimen C432 after 100 cycles of accelerated degradation by chlorides

Slika 13: Razpoka v vzorcu C432 po 100 ciklih pospešene degradacije s kloridi

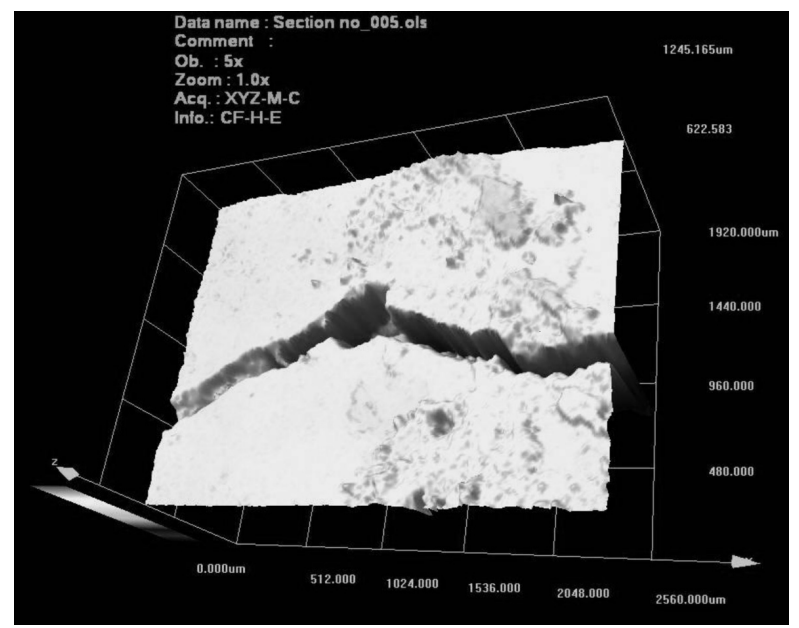

Figure 14: Crack in specimen C435 after 40 cycles of accelerated degradation by chlorides

Slika 14: Razpoka v vzorcu C435 po 40 ciklih pospešene degradacije s kloridi shifts during the degradation are shown with the graph in Figure 9. Figure 10 shows changes in the dominant frequency for sample C435. The development-frequency spectrum during the degradation of this sample has the same tendency as sample C432 and as all the other samples. The value of the dominant frequency before the carbonation of the concrete was $10677 \mathrm{~Hz}$; after the carbonation, it was $9918 \mathrm{~Hz}$ and after the corrosion, it was $9579 \mathrm{~Hz}$.

Using the confocal microscope LEXT 3100, we monitored the state of the surface and the cracks of the concrete samples during the degradation. We always scanned the same place on the surface. We were particularly interested in the growth of the cracks. In Figures $\mathbf{1 1}$ to $\mathbf{1 3}$ (for sample C432) and in Figures $\mathbf{1 4}$ to $\mathbf{1 6}$ (for sample C435) we can see a gradual expansion of the cracks during the degradation process.

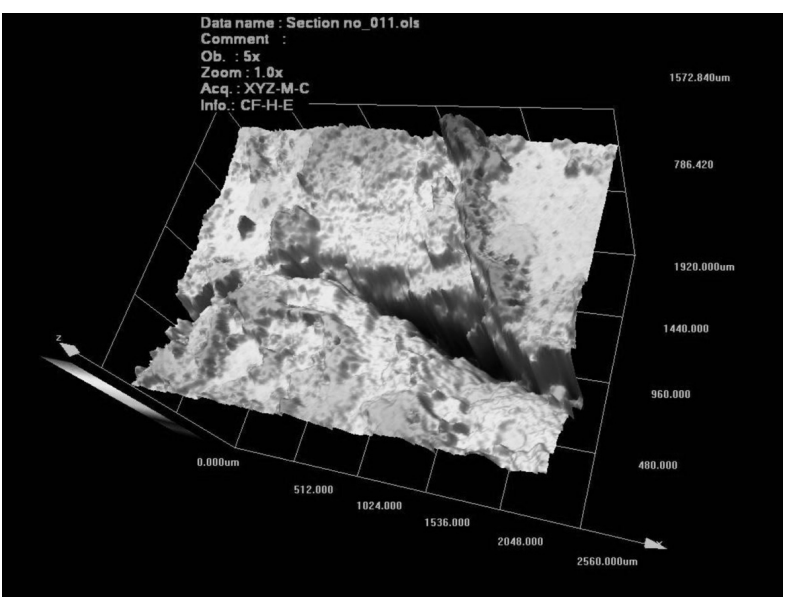

Figure 15: Crack in specimen C435 after 60 cycles of accelerated degradation by chlorides

Slika 15: Razpoka v vzorcu C435 po 60 ciklih pospešene degradacije s kloridi

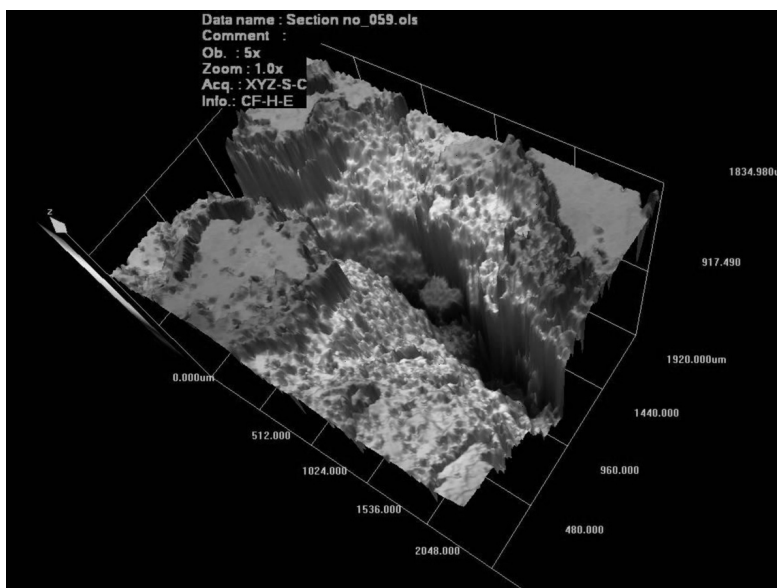

Figure 16: Crack in specimen C435 after 100 cycles of accelerated degradation by chlorides

Slika 16: Razpoka v vzorcu $\mathrm{C} 435$ po 100 ciklih pospešene degradacije s kloridi 


\section{CONCLUSIONS}

This paper presents our results for monitoring the corrosion of concrete-covered steel by means of nonlinear ultrasonic spectroscopy using a single exciting harmonic ultrasonic frequency and the impact-echo method.

For the NUS method, it is essential to minimize any harmonic distortion in the signal pick-up and amplification path by eliminating any interfering signals (noise, parasitic signal) from the measuring apparatus. A very good mechanical coupling must also be ensured between the exciter and the specimen and between the specimen and the piezoceramic sensor during the measurement. It was proved that structural defects, which are due to steel corrosion, give rise to non-linear effects. We can see significant amplitude changes, especially the third-harmonic amplitude changes and the growth of non-harmonic frequencies.

The results of the impact-echo method proved that this method is very sensitive to the damage of a concrete structure by carbonation and corrosion. The shifts of the dominant frequencies obtained with the fast Fourier transform from the response signal correspond with the changes in the structure during the degradation. It was shown that the deteriorating state of the structure has an effect on the reduction in the dominant frequencies.

The growth of the cracks was also proved with confocal microscopy. Based on this, we can say that both methods are very promising for monitoring steel corrosion in concrete.

\section{Acknowledgments}

This paper was completed within project No. LO1408 "AdMaS UP - Advanced Materials, Structures and Technologies", supported by the Ministry of Education, Youth and Sports under the "National Sustainability Programme I", project GA13-18870S of the Czech Science Foundation and specific research program at the Brno University of Technology, project No. FAST-S15-2622.

\section{REFERENCES}

${ }^{1}$ M. Collepardi, The New Concrete, 1st ed, Tintoretto, 2006, 421, ISBN: 9788890146947

${ }^{2}$ K. E. Van Den Abeele, A. Sutin, J. Carmeliet, P. A. Johnson, Microdamage diagnostics using nonlinear elastic wave spectroscopy (NEWS), NDT \& E International, 34 (2001) 4, 239-248, doi:10.1016/S0963-8695(00)00064-5

${ }^{3}$ V. Zaitsev, V. Nazarov, V. Gusev, B. Castagnede, Novel nonlinear-modulation acoustic technique for crack detection, NDT \& E International, 39 (2006) 3, 184-194, doi:10.1016/j.ndteint.2005. 07.007

${ }^{4}$ L. Pazdera, L. Topolar, Application acoustic emission method during concrete frost resistance, Russian Journal of Nondestructive Testing, 50 (2014) 2, 127-132, doi:10.1134/S1061830914020065

${ }^{5}$ L. Pazdera, L. Topolar, J. Smutny, V. Rodriguezova: Modulus of Elasticity Determination from Cantilever Deflection, Proc. of the 50th Annual Conference on Experimental tress Analysis, Praha, 2012, 313-320, ISBN 978-80-01-05060-6

${ }^{6}$ H. S. Limaye, R. J. Krause, Nondestructive evaluation of concrete with impact-echo and pulse- velocity techniques, Materials Evaluation, 49 (1991) 10, 1312-1315, doi:10.1016/S0963-8695(97) 88984-0

${ }^{7}$ M. T. Liang, P.J. Su, Detection of the corrosion damage of rebar in concrete using impact-echo method, Cement and Concrete Research, 31 (2001) 10, 1427-1436, doi:10.1016/S0008-8846(01)00569-5

${ }^{8}$ M. Matysik, I. Plskova, Z. Chobola, Estimation of Impact-Echo Method for the Assessment of Long-Term Frost Resistance of Ceramic Tiles, Advanced Materials Research, 1000 (2014), 285-288, doi:10.4028/www.scientific.net/AMR.1000.285

${ }^{9}$ G. Epasto, E. Proverbio, V. Venturi, Evaluation of fire-damaged concrete using impact-echo method, Materials and Structures, 43 (2010) 1-2, 235-245, doi:10.1617/s11527-009-9484-0

${ }^{10}$ B. Kucharczykova, P. Misak, T. Vymazal, Determination and evaluation of the air permeability coefficient using Torrent Permeability Tester, Russian Journal of Nondestructive Testing, 46 (2010) 3, 226-233, doi:10.1134/S1061830910030113

${ }^{11}$ M. Krause, M. Barmann, R. Frielinghaus, Comparison of pulse-echo methods for testing concrete, NDT \& E International, 30 (1997) 4, 195-204, doi:10.1016/S0963-8695(96)00056-4

${ }^{12}$ T. Vymazal, N. Zizkova, P. Misak, Prediction of the risks of design and development of new building materials by fuzzy inference systems, Ceramics-Silikáty, 53 (2009) 3, 216-224, ISSN 0862-5468

${ }^{13}$ D. N. Boccaccini, M. Maioli, M. Cannio, M. Romagnoli, P. Veronesi, C. Leonelli, A. R. Boccaccini, A statistical approach for the assessment of reliability in ceramic materials from ultrasonic velocity measurement: Cumulative Flaw Length Theory, Engineering Fracture Mechanics, 76 (2009) 11, 1750-1759, doi:10.1016/ j.engfracmech.2009.03.008 